\title{
Resources and Capabilities From Their Very Outset: A Bibliometric Comparison Between Scopus and the Web of Science
}

\author{
Mileidy Alvarez-Melgarejo ${ }^{1}$, Martha L. Torres-Barreto ${ }^{2}$ \\ ${ }^{1}$ Porter Research Group, Universidad de Investigación y Desarrollo, Bucaramanga, Colombia \\ 2 Finance \& Managament Research Group, School of Industrial and Business Studies, Universidad Industrial de \\ Santander, Bucaramanga, Colombia \\ Correspondence: Martha L. Torres Barreto, School of Industrial and Business Studies, Universidad Industrial de \\ Santander, Bucaramanga, Colombia, ON., Cra 27 Calle 9, Bucaramanga, Santander. Tel: 057-6344000. Ext. 2207. E-mail: \\ mltorres@uis.edu.co
}

Received: May 18, 2018 Accepted: June 25, 2018 Online Published: July 26, 2018

doi:10.5539/res.v10n4p1 URL: https://doi.org/10.5539/res.v10n4p1

\begin{abstract}
The bibliometric method has proven to be a powerful tool for the analysis of scientific publications, in such a way that allows rating the quality of the knowledge generating process, as well as its impact on firm's environment. This article presents a comparison between two powerful bibliographic databases in terms of their coverage and the usefulness of their content. The comparison starts with a subject associated to the relationship between resources and capabilities. The outcomes show that the search results differ between both databases. The Web Of Science (WOS), has a greater coverage than SCOPUS has. It also has a greater impact in terms of most cited authors and publications. The search results in the WOS yield articles from 2001, while Scopus yields articles from 1976, however, some of the latter are inconsistent with the topic being searched. The analysis points to a lack of studies regarding resources as foundations of firm's capabilities; as a result, new research on this field is suggested.
\end{abstract}

Keywords: bibliometric analysis, capabilities, resources, resource based view of the firm, Scopus, Web of Science

\section{Introduction}

Scientific research expressed in written documents is the driving force of science (Van Raan, 2003), also, the continuous growth of scientific production, as well as its collection in databases, has boosted the use of bibliometric analysis (Filippo \& Fernández, 2002; Solano López, Castellanos Quintero, López Rodríguez del Rey, \& Hernández Fernández, 2009). This method of quantitative character provides information on the growth, evolution, structure, and visibility of the literature, as well as the tendencies of a specific topic using diverse indicators (Albort-Morant and Ribeiro-Soriano 2016; Van Raan 2003). The most used ones are known as basic metrics (Albort-Morant, Leal-Rodríguez, Fernández-Rodríguez, \& Ariza-Montes, 2017; Haustein \& Larivière, 2015). They measure the productivity of academics, countries and indexed journals and also analyze the databases information retrieval capacity (Falagas, Pitsouni, Malietzis, \& Pappas, 2008) and the impact of papers and journals, measured through the number of citations received and the $\mathrm{H}$ index (De Bakker, Groenewegen, \& Den Hond, 2005).

In spite of the benefits described below, bibliometric analysis seems to differ when the work is performed using different databases, which may lead to odd results, and consequently, may indeed, vary the course of a research, depending on the selection made. These facts turn the choice of the database into an even more relevant decision. Considering the above, this document presents a bibliometric comparison between WOS and Scopus: two powerful world-wide known databases. The study tries to demonstrate that coverage, impact and specific results of a certain topic-search, may vary from database to database. To do so, the same search equation was used on documents associated to the relationship between resources and capabilities of firms, according to the Research Based View Theory of Firms (RBV). The comparison allows to identify differences between both databases, while offers a general overview of the subject, reveals the progress of the research over time and the areas that require more theoretical and empirical research. It also serves as an introductory reference and preliminary focus for new researchers who wish to delve into the subject.

The document begins with the bibliometric analysis; then describe the methodology used to analyze the information obtained from the databases; followed by the discussion of the results, and ends with the conclusions of the study. 


\section{1 Bibliometrics and Its Importance}

Bibliometrics is understood as the quantification of the production and consumption of bibliographic information (Rueda-Klaussen Gómez, Villa-Roel Gutíerrez, \& Rueda-Klaussen Pinzón, 2005). It dates back to the beginning of the 20th century (Bordons \& Zulueta, 1999; Haustein \& Larivière, 2015; Osareh, 1996), when it was used as a tool for the development of journal collections (Haustein and Larivière 2015). However, from the last two decades, this discipline has experienced an increased importance due to technological advances (Bordons \& Zulueta, 1999), and also due to the use of mathematical models and refined statistics, which have allowed to examine the scientific activity and productivity on an easier way (Albort-Morant et al., 2017; Albort-Morant \& Ribeiro-Soriano, 2016; Daim et al., 2006). By using a bibliometrics set of tools, evaluations on the research quality can be performed, and concrete measures of productivity by journals, countries, and authors are feasible (Abramo and D'Angelo 2011).

Notwithstanding that numerous academics point at scientific databases as the main source for powerful bibliometric analysis (Granda-Orive et al., 2013), bibliometrics extensively depends on the database chosen. Few years ago, the WOS was the only practical tool used to measure the impact of articles, journals, and researchers. Nevertheless, since 2004, other databases like Scopus and Google Scholar have also been used for this purpose (Abramo \& D'Angelo, 2011; Kulkarni et al., 2009). This fact has facilitated the searching for a specific topic and the analysis of the content's importance (Falagas et al., 2008). Bibliometrics has then become an important tool for researchers; therefore, in the literature we can find bibliometric studies that focus on counting citations of a particular topic (Bauer \& Bakkalbasi, 2005; Falagas et al., 2008; Jacsó, 2005; Kulkarni et al., 2009; Meho \& Rogers, 2008; Noruzi, 2005), or the number of articles and types of journals in a specific area of knowledge within certain period of time. This studies share a common objective, which is to identify the importance of the manuscripts, and, to measure the increase in knowledge in a particular area and its tendencies. As important as this measurements, is to grade the consistency and differences in search results among different databases. For this particular research, the WOS and Scopus were selected given their strong coverage on peer-reviewed journals (Kulkarni et al., 2009). The base for the comparison was "the relationship between resources and capabilities"; a topic that happens to be relevant in the field of strategic management, considering the importance of the resources and capabilities as sources of competitive advantages (Lache, León, Bravo, Becerra, \& Forero, 2016; Teece, Pisano, \& Shuen, 1997; Torres-Barreto \& Antolinez, 2017; Torres-Barreto, Martínez, Meza-Ariza, \& Molina, 2016). Related to this research topic, there are numerous references in the literature that highlight resources as founders of capabilities (Helfat \& Peteraf, 2003; Schriber \& Löwstedt, 2015), and some others that remark a relationship between R\&C and firm's productivity, or financial results (Cruz, López, \& Martín, 2009; Escandón, Rodriguez, \& Hernández, 2013; Ray, Barney, \& Muhanna, 2004; Rivera \& Figueroa, 2013). Another group of studies point out a relationship between R\&C and the creation of competitive advantages (Barney, 1991, 2001, 2007; Dierickx \& Cool, 1989; King, 2007; Ma, 1999a, 1999b; Morgan, Kaleka, \& Katsikeas, 2004; Phusavat \& Kanchana, 2007; Priem \& Butler, 2001b, 2001a; Santhapparaj, Sreenivasan, \& Loong, 2006; Sirmon, Hitt, \& Ireland, 2007; Torres-Barreto, 2017; Torres-Barreto, Mendez-Duron, \& Hernandez-Perlines, 2016; Wernerfelt, 1984; Wiklund \& Shepherd, 2003). Based on this previous findings, the intention of this paper is to compare the performance of two powerful databases with respect to an specific search equation and by this way, to deal out with the problem of differences among search results that may lead a researcher to alter the course of their investigation.

\section{Method}

In this study we conducted an analysis of productivity, publications and author indicators. We intended to compare the results obtained by using the same search equation in both databases. WOS and Scopus coincide in providing scientific information of articles as well as other academic publications, however, the first source of difference identified was related to the grouping by areas of knowledge. While in WOS we had: economics, administration, and business, in Scopus we had: business, administration-accounting, economics, econometrics, and finance. This fact was considered as a preliminary cause of differences among databases search results.

The next step was to compare the productivity (through the number of publications); and the impact of publications (through the number of citations) (Albort-Morant et al., 2017; Albort-Morant \& Ribeiro-Soriano, 2016; Cadavid-Higuita, Awad, \& Franco-Cardona, 2012). By measuring this two items, we also intended to determine how the academic interest on the relationship between resources and capabilities has grown over time. 

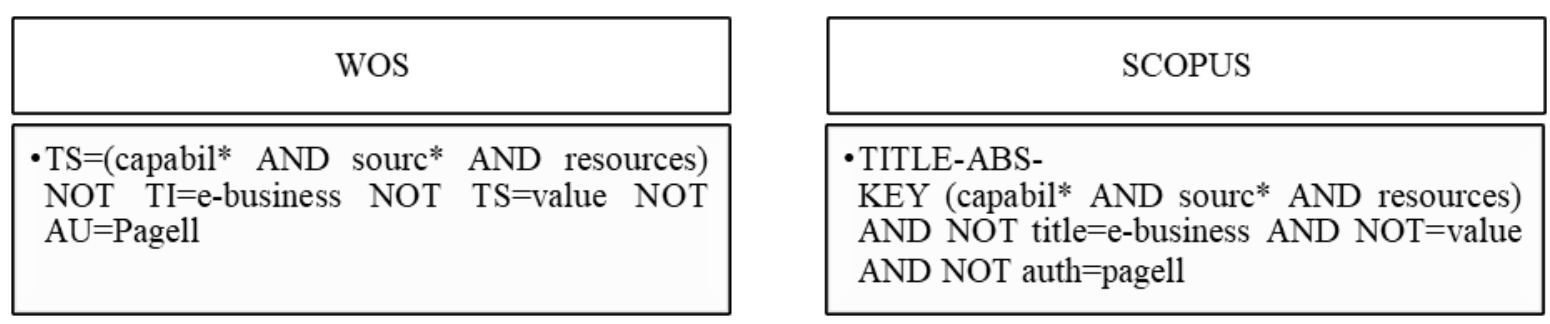

Figure 1. Search equations

Regarding the search equation used (See Figure 1), after being built-up it was validated through consultation of various experts. Boolean operators were used to include, group and exclude terms of interest. The search commands lightly differ from one equation to the other due to small differences in the configuration language between both databases. In this case, "source" was the word that better define the relationship between resources and capabilities in different articles. Furthermore, the terms "e-business" and "value", were excluded since the many manuscripts that contained them, didn't relate to the subject of study. It also happened with the author: Pagell. We also selected the areas of knowledge according to the importance of the subject in the field of strategic management and, the interval of the study was 2001 to 2016.

\section{Results}

By executing the search equation in both databases we obtained 258 documents in the WOS, (237 were articles). And 189 in Scopus, (106 articles). Since this study exclusively considers the research articles; the remaining documents were excluded. Within this search results we analyzed:

- The number of research articles that explore the relationship between resources and capabilities (2001 to 2006).

- The countries with higher productivity.

- The more productive authors.

- The journals with a higher number of publications.

- The most cited articles.

The next finding was related to the coverage of databases, having found 39 articles that coincide in both of them. From those that do not coincide, 198 belong to the WOS and 67 to Scopus, pointing out a higher coverage by the WOS database. Regarding the databases effectiveness, we found that the percentage of articles that indeed study the relationship between resources and capabilities were $20 \%$ in the WOS Vs. $19 \%$ in Scopus, which indicates a marginal relevance of the WOS. It was also found that 19 articles have no citations in the WOS, while in Scopus there are 24 articles without any citations, which leads to the conclusion that the WOS articles are more visible and consequently more cited.

\subsection{Comparison Regarding Year of Publication}

The study of the relationship between R\&C became relevant in the WOS since 2001, meanwhile in Scopus it began relevant in 1976; however, most of the Scopus publications are not specifically related to the study of the relationship among Resources and Capabilities, some of them analyse a particular resource, or review the relationship between strategy and competitive advantage, and, in some other cases the content of the article doesn't precisely match the topic of study. Considering the previous facts, we may say that this topic became relevant in 2001 (see Figure 2).

Another item of study comprises the quantity of manuscripts published per year within the field of study. Both databases register at least 6 publications per year from 2001, and this number has been increasing over the next 15 years, keeping a growing tendency in Scopus, while registering some inflection points towards increase and decline in the WOS. The highest number of published researches was registered in 2010 for both databases (27 articles in WOS Vs. 12 in Scopus). Between 2014 and 2015 the number of publications was stable in the WOS, and this number decreased in 2016. Scopus exhibit a decreasing tendency from 2013 to 2016. 


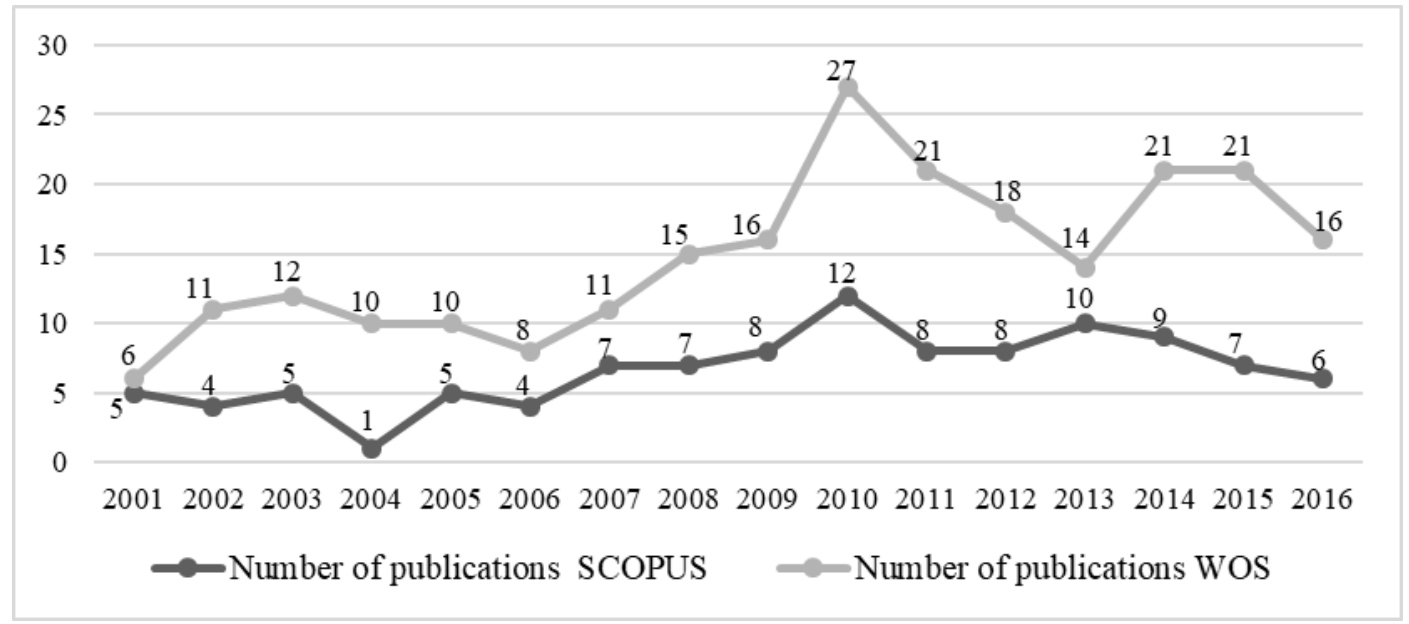

Figure 2. Evolution of the number of publications regarding the relationship between R\&C.

Source: WOS and Scopus.

\subsection{Comparison Regarding Productivity by Countries}

Tables 1 and 2 show the top 20 countries by productivity. Productivity by country is measured through the total number of papers published per year (TP), the total number of citations (TC), the average number of citations per published paper $(\mathrm{C} / \mathrm{P})$ and the H-index. The analysis of both databases yields that the United States of America is positioned as the top country in terms of number of publications (WOS 100 Vs. Scopus 32 documents), it also exhibit the highest number of citations (WOS 5.122 Vs. Scopus 2.762) and the highest H-index (WOS 33 Vs. Scopus 18). These results could be attributed to the amount of money devoted to research in the United States, and also to the degree of access to databases by the side of researchers in that country.

For the rest of the countries the results vary from one database to the other: countries that have a leading productivity position in the WOS, do not maintain this position in Scopus, however, regardless of their position in the list of the top 20, the countries in both databases are mostly the same ones, except Singapore, Turkey, Belgium, Portugal and Hong Kong.

Further observation identifies that the highest productivity of a country does not suggest the highest number of citations. Such is the case of Belgium ( 3 articles and 287citations in total) and Brazil (5 articles and 22 citations) See Table 1. Something similar occurs in Germany (2 articles and 121 citations. See Table 2). There are also some countries with a small number of citations, this could be due to the novelty character of this papers, or alternatively, that their works can be considered of less academic value.

For Belgium's case, the paper with the highest number of citations refers to the relationship between the firms capability to relate to others within the same sector; and the resources generated by strategic alliances and acquisitions (Vanhaverbeke, Duysters, \& Noorderhaven, 2002).

Table 1 . Top 20 of productivity by country in the WOS

\begin{tabular}{rrrrrr}
\hline Rank & Country & TP & TC & C/P & H-index \\
\hline 1 & United States & 100 & 5.122 & 51,22 & 33 \\
2 & England & 24 & 596 & 24,83 & 11 \\
3 & Spain & 18 & 273 & 15,17 & 7 \\
4 & Australia & 15 & 217 & 14,47 & 7 \\
5 & China & 14 & 248 & 17,71 & 7 \\
6 & Taiwan & 14 & 310 & 22,14 & 9 \\
7 & Germany & 13 & 700 & 53,85 & 10 \\
8 & South Korea & 11 & 110 & 10,00 & 7 \\
\hline
\end{tabular}




\begin{tabular}{rrrrrr}
\hline 9 & France & 10 & 514 & 51,40 & 9 \\
10 & Netherlands & 9 & 693 & 77,00 & 9 \\
11 & Italy & 8 & 202 & 25,25 & 3 \\
12 & Sweden & 8 & 305 & 38,12 & 6 \\
13 & Canada & 6 & 83 & 13,83 & 4 \\
14 & Denmark & 6 & 304 & 50,67 & 3 \\
15 & Brazil & 5 & 22 & 4,40 & 2 \\
16 & Singapore & 4 & 192 & 48,00 & 3 \\
17 & Turkey & 4 & 23 & 5,75 & 4 \\
18 & Belgium & 3 & 287 & 95,67 & 3 \\
19 & Malaysia & 3 & 2 & 0,67 & 1 \\
20 & Portugal & 3 & 8 & 2,67 & 2 \\
\hline
\end{tabular}

Table 2. Top 20 of productivity by country in Scopus

\begin{tabular}{|c|c|c|c|c|c|}
\hline Rank & Country & TP & TC & $\mathbf{C} / \mathbf{P}$ & H-index \\
\hline 1 & United States & 32 & 2.762 & 86,31 & 18 \\
\hline 2 & Australia & 8 & 158 & 19,75 & 5 \\
\hline 3 & China & 8 & 85 & 10,63 & 3 \\
\hline 4 & France & 7 & 271 & 38,71 & 4 \\
\hline 5 & United Kingdom & 7 & 61 & 8,71 & 4 \\
\hline 6 & Malaysia & 5 & 6 & 1,20 & 1 \\
\hline 7 & Brazil & 4 & 9 & 2,25 & 1 \\
\hline 8 & Russian Federation & 4 & 49 & 12,25 & 2 \\
\hline 9 & Spain & 4 & 43 & 10,75 & 2 \\
\hline 10 & Taiwan & 4 & 28 & 7,00 & 2 \\
\hline 11 & Canada & 3 & 105 & 35,00 & 2 \\
\hline 12 & Denmark & 3 & 35 & 11,67 & 3 \\
\hline 13 & Sweden & 3 & 24 & 8,00 & 2 \\
\hline 14 & Czech Republic & 2 & 2 & 1,00 & 1 \\
\hline 15 & Germany & 2 & 121 & 60,50 & 2 \\
\hline 16 & Hong Kong & 2 & 144 & 72,00 & 2 \\
\hline 17 & India & 2 & 1 & 0,50 & 1 \\
\hline 18 & Israel & 2 & 20 & 10,00 & 2 \\
\hline 19 & Italia & 2 & 205 & 102,50 & 1 \\
\hline 20 & Netherlands & 2 & 38 & 19,00 & 2 \\
\hline
\end{tabular}

Tables 3 and 4 show the number of papers published in the 10 most productive countries. The United States is in the top of the list for both databases, however, the reduced number of total papers published up to these days make evident that the connection between the set of resources that the company poses and the capabilities it develops still haven't been addressed significantly, leaving gaps open to being studied. 
Table 3. Top 10 of countries by productivity. WOS. 2001-2016

\begin{tabular}{|c|c|c|c|c|c|c|c|c|c|c|}
\hline Year & $\begin{array}{l}\text { United } \\
\text { States }\end{array}$ & England & Spain & Australia & China & Taiwan & Germany & $\begin{array}{l}\text { South } \\
\text { Korea }\end{array}$ & France & Netherlands \\
\hline 2001 & 3 & 0 & 0 & 2 & 1 & 0 & 0 & 0 & 0 & 0 \\
\hline 2002 & 8 & 0 & 0 & 1 & 0 & 0 & 0 & 0 & 0 & 2 \\
\hline 2003 & 6 & 0 & 0 & 0 & 0 & 1 & 0 & 0 & 2 & 1 \\
\hline 2004 & 5 & 1 & 0 & 0 & 0 & 1 & 0 & 1 & 0 & 0 \\
\hline 2005 & 8 & 1 & 0 & 0 & 0 & 1 & 0 & 0 & 0 & 0 \\
\hline 2006 & 1 & 1 & 0 & 0 & 0 & 0 & 1 & 0 & 1 & 3 \\
\hline 2007 & 2 & 2 & 0 & 0 & 0 & 2 & 0 & 0 & 1 & 0 \\
\hline 2008 & 8 & 1 & 2 & 2 & 0 & 1 & 0 & 0 & 1 & 1 \\
\hline 2009 & 10 & 1 & 1 & 2 & 1 & 0 & 1 & 1 & 2 & 0 \\
\hline 2010 & 8 & 4 & 2 & 0 & 0 & 4 & 5 & 1 & 0 & 1 \\
\hline 2011 & 7 & 2 & 3 & 0 & 1 & 0 & 2 & 2 & 1 & 0 \\
\hline 2012 & 6 & 2 & 1 & 1 & 3 & 2 & 1 & 1 & 0 & 0 \\
\hline 2013 & 8 & 1 & 1 & 1 & 2 & 1 & 0 & 2 & 1 & 1 \\
\hline 2014 & 10 & 2 & 5 & 3 & 0 & 1 & 0 & 2 & 1 & 0 \\
\hline 2015 & 9 & 1 & 1 & 0 & 2 & 0 & 3 & 0 & 0 & 0 \\
\hline 2016 & 1 & 5 & 2 & 3 & 4 & 0 & 0 & 1 & 0 & 0 \\
\hline
\end{tabular}

Table 4. Top 10 of countries by productivity - Scopus. 2001-2016

\begin{tabular}{ccccccccccc}
\hline Year & $\begin{array}{c}\text { United } \\
\text { States }\end{array}$ & Australia & China & France & $\begin{array}{c}\text { United } \\
\text { Kingdom }\end{array}$ & Malaysia & Brazil & $\begin{array}{c}\text { Russian } \\
\text { Federation }\end{array}$ & Spain & Taiwan \\
\hline 2001 & 1 & 3 & 0 & 0 & 1 & 0 & 0 & 0 & 0 & 0 \\
2002 & 3 & 1 & 0 & 0 & 0 & 0 & 0 & 0 & 1 & 0 \\
2003 & 4 & 0 & 0 & 0 & 0 & 0 & 0 & 0 & 0 & 0 \\
2004 & 1 & 0 & 0 & 0 & 0 & 0 & 0 & 0 & 0 & 0 \\
2005 & 2 & 0 & 1 & 0 & 1 & 0 & 1 & 0 & 1 & 0 \\
2006 & 1 & 0 & 2 & 0 & 0 & 0 & 0 & 0 & 0 & 0 \\
2007 & 3 & 0 & 0 & 0 & 0 & 0 & 0 & 0 & 0 & 0 \\
2008 & 3 & 1 & 1 & 0 & 0 & 0 & 0 & 0 & 0 & 0 \\
2009 & 3 & 0 & 1 & 3 & 0 & 1 & 0 & 1 & 1 & 1 \\
2010 & 2 & 1 & 1 & 0 & 0 & 1 & 0 & 1 & 0 & 1 \\
2011 & 1 & 0 & 0 & 0 & 1 & 0 & 1 & 0 & 0 & 0 \\
2012 & 2 & 0 & 0 & 0 & 0 & 1 & 1 & 0 & 0 & 0 \\
2013 & 1 & 0 & 0 & 1 & 1 & 1 & 1 & 0 & 0 & 1 \\
2014 & 3 & 0 & 1 & 0 & 2 & 0 & 0 & 0 & 0 & 1 \\
2015 & 1 & 1 & 0 & 1 & 1 & 0 & 0 & 2 & 1 & 0 \\
2016 & 1 & 1 & 1 & 2 & 0 & 1 & 0 & 0 & 0 & 0 \\
\hline
\end{tabular}

The United States register 10 WOS articles published in 2009 and 10 in 2014, while in Scopus the most productive year was 2003 with 4 publications. The particular topics studied in this papers, are the different sources of capabilities, including some resources as generators of firms capabilities (Chadwick \& Dabu, 2009; Colakoglu, Yamao, \& Lepak, 2014; Helfat \& Peteraf, 2003; McKelvie \& Davidsson, 2009; Morris, Hammond, \& Snell, 2014), also some capabilities 
that enhance capabilities and influences the generation of resources (Hervas-Oliver, Sempere-Ripoll, \& Boronat-Moll, 2014; Kleinbaum \& Stuart, 2014; Weeks, 2009), as well as the study of some type of resource or capability and its influence in the company's performance and competitive advantage.

\subsection{Comparison Regarding Productivity by Authors}

There is just one common author between WOS and Scopus in the top 20 list of productive authors. Nevertheless, if we observe the total list of authors, there are 86 in common, including Lengnick-Hall, Helfat, Peteraf, Habbershon, Williams, MacMillan, Verona, Ravasi, Foerstl, Reuter, Hartmann, Chadwick, and Dabu. By other hand, WOS exhibit higher $\mathrm{H}$-indices per author $(\mathrm{H}=3$ and $\mathrm{H}=2)$, compared to Scopus $(\mathrm{H}=0$ or $\mathrm{H}=1)$, which points out a greater impact of the WOS.

Regarding number of citations per article, the papers that stand out, study the importance of capabilities, their origins and the influence in the performance of the company (Ethiraj, Kale, Krishnan, \& Singh, 2005), and firms preferences for external sources in order to develop innovative capabilities (Hagedoorn and Duysters 2002; Vanhaverbeke, Duysters, and Noorderhaven 2002). Regarding the analysis by authors, there are highly relevant differences between both databases, being the WOS the one with the greatest number of citations per author (Scopus=119 cites per author, while WOS=172).

Table 5. WOS: Influential authors regarding the relationship between R\&C

\begin{tabular}{lcrrc}
\hline \multicolumn{1}{c}{ Authors } & TP & TC & \multicolumn{1}{c}{ C/P } & H-index \\
\hline Bowman C & 3 & 42 & 14,00 & 3 \\
Hartmann E & 3 & 245 & 81,67 & 3 \\
Kaufmann L & 3 & 75 & 25,00 & 3 \\
Duysters G & 3 & 408 & 136,00 & 3 \\
Lengnick-Hall CA & 3 & 113 & 37,67 & 2 \\
Lengnick-Hall ML & 3 & 122 & 40,67 & 3 \\
Ambrosini V & 2 & 25 & 12,50 & 2 \\
Blome C & 2 & 221 & 110,50 & 2 \\
Collier N & 2 & 24 & 12,00 & 2 \\
Foerstl K & 2 & 221 & 110,50 & 2 \\
Grimpe C & 2 & 164 & 82,00 & 2 \\
Hervas-Oliver JL & 2 & 53 & 26,50 & 2 \\
Hyland P & 2 & 34 & 17,00 & 2 \\
Kale P & 2 & 344 & 172,00 & 2 \\
Lau A & 2 & 80 & 40,00 & 2 \\
Lee Ruby P & 2 & 15 & 7,50 & 1 \\
Lin BW & 2 & 89 & 44,50 & 2 \\
Manning S & 2 & 21 & 10,50 & 2 \\
Reuter C & 2 & 221 & 110,50 & 2 \\
Sofka W & 2 & 164 & 82,00 & 2 \\
\hline
\end{tabular}


Table 6. SCOPUS: Influential authors regarding the relationship between R\&C.

\begin{tabular}{lcrrc}
\hline \multicolumn{1}{c}{ Authors } & TP & TC & C/P & H-index \\
\hline Capron, L. & 2 & 114 & 57 & 1 \\
Abrahamsson, M. & 1 & 21 & 21 & 1 \\
Afshar, A. & 1 & 64 & 64 & 1 \\
Aggarwal, A.K. & 1 & 1 & 1 & 1 \\
Ahn, M.J. & 1 & 36 & 36 & 1 \\
Al-Athari, A. & 1 & 34 & 34 & 1 \\
Anderson, E. & 1 & 1 & 1 & 1 \\
Bañón, A.R. & 1 & 10 & 10 & 1 \\
Beckmann, S. & 1 & 2 & 2 & 1 \\
Beltrán, J. & 1 & 0 & 0 & 0 \\
Bertrand, O. & 1 & 47 & 47 & 1 \\
Best, M.H. & 1 & 10 & 10 & 1 \\
Beyhan, B. & 1 & 5 & 5 & 1 \\
Blome, C. & 1 & 119 & 119 & 1 \\
Bonvillian, W.B. & 1 & 5 & 5 & 1 \\
Boright, J.P. & 1 & 1 & 1 & 1 \\
Boylan, R.L. & 1 & 55 & 55 & 1 \\
Bravo-Ibarra, E.R. & 1 & 2 & 2 & 1 \\
Brettel, M. & 1 & 2 & 2 & 1 \\
Brush, T.H. & 1 & 50 & 50 & 1 \\
\hline
\end{tabular}

\subsection{Comparison Regarding Productivity by Journals}

The study found 102 journals in the WOS Vs. 86 in Scopus exploring the relationship between resources and capabilities. Tables 7 and 8 display the top 20 journals and its impact factor. WOS top journals are: Strategic Management Journal and Technovation, (12 papers each). Scopus top Journals are: Asian Journal of Technology Innovation, the International Business Management and Technological Forecasting and Social Change (3 publications each). We may say that the impact factor per journal differs in both databases, and, that it is probably due to the different number of publications identified by each database search engine, being the WOS the one that has the greatest coverage and impact.

Lastly, an individual analysis by journal reveals that the journal with the highest impact factor is not always the most productive one. As an example: The Academy of Management Journal has only 1 publication registered in Scopus and has an H-index=10,34, compared to the most productive journal in WOS: The Strategic Management Journal, with 12 publications and a $\mathrm{H}=4.461$. We can deduce that top productive journals of WOS are more cited than top productive journals of Scopus, for this particular area of study.

Table 7. WOS most productive journals

\begin{tabular}{cclc}
\hline Rank & Number of publications & \multicolumn{1}{c}{ Journals } & Impact factor 2016 \\
\hline 1 & 12 & Strategic Management Journal & 4.461 \\
2 & 12 & Technovation & 3.265 \\
3 & 7 & Journal of International Business Studies & 5.869 \\
4 & 7 & R \& D Management & 2.444 \\
5 & 7 & Technological Forecasting and Social Change & 2.625 \\
6 & 6 & IEEE Transactions on Engineering Management & 1.188 \\
7 & 6 & International Journal of Technology Management. & 1.036 \\
\hline
\end{tabular}




\begin{tabular}{clll}
\hline 8 & 5 & Industrial and Corporate Change & 1.777 \\
9 & 5 & Journal of International Marketing & 3.725 \\
10 & 5 & Journal of Supply Chain Management & 5.789 \\
11 & 5 & Journal of World Business & 3.758 \\
12 & 5 & Organization Science & 2.691 \\
13 & 5 & Research Policy & 4.495 \\
14 & 4 & Asian Journal of Technology Innovation & 0.698 \\
15 & 4 & British Journal of Management & 2.982 \\
16 & 4 & Industrial Marketing Management & 3.166 \\
17 & 4 & Innovation Management Policy \& Practice & 0.950 \\
18 & 4 & International Journal of Human Resource Management & 1.650 \\
19 & 4 & Journal of Management Studies & 3.962 \\
20 & 4 & Asian Business \& Management & 1.133 \\
\hline
\end{tabular}

Table 8. Scopus most productive journals

\begin{tabular}{cclc}
\hline Rank & Number of publications & \multicolumn{1}{c}{ Journals } & Impact factor 2016 \\
\hline 1 & 3 & Asian Journal of Technology Innovation & 0.429 \\
2 & 3 & International Journal of Technology Management & 0.450 \\
3 & 3 & Technological Forecasting and Social Change & 1.247 \\
4 & 2 & Advances In Applied Business Strategy & 0.149 \\
5 & 2 & Economy of Region & 0.260 \\
6 & 2 & Espacios & 0.170 \\
7 & 2 & Industrial and Corporate Change & 1.835 \\
8 & 2 & International Business Management & 0.194 \\
9 & 2 & International Journal of Emerging Markets & 0.260 \\
10 & 2 & International Journal of Project Management & 1.396 \\
11 & 2 & Journal of Business Venturing & 5.771 \\
12 & 2 & Journal of Strategic Marketing & 0.328 \\
13 & 2 & Journal of The Knowledge Economy & 0.534 \\
14 & 2 & Mediterranean Journal of Social Sciences & 0.139 \\
15 & 2 & Organization Science & 5.870 \\
16 & 2 & Research Policy & 3.625 \\
17 & 2 & Strategic Management Journal & 7.651 \\
18 & 1 & Academy of Management Executive & 4.599 \\
19 & 1 & Academy of Management Journal & 10.346 \\
20 & 1 & Accounting and Business Research & 0.945 \\
\hline
\end{tabular}

\subsection{Comparison Regarding Citations by Papers}

The most cited paper (The dynamic resource-based view: capability lifecycles), was published in 2003 by Helfat and Peteraf. (993 citations in WOS Vs. 1.234 in Scopus). It addresses the concept of the evolutionary lifecycle of capabilities. The study considers that capabilities are originated in a group of individuals with distinctive characteristics and a common objective that implies to generate an ability. They later move into a development stage, where highly depend on what the individuals can achieve with the available resources. Lastly, they enter a stage of maturity, incorporating themselves in the memory of the organization. 
The analysis of the highly relevant papers in both databases shows that most of them study the relationship between resources and capabilities, or the influence of resources on capabilities. See Tables 9 and 10.

Table 9. WOS: Most cited papers about the relationship between R\&C

\begin{tabular}{|c|c|c|c|}
\hline Rank & TC & Authors & Title \\
\hline 1 & 993 & Helfat \& Peteraf (2003) & The dynamic resource-based view: Capability lifecycles. \\
\hline 2 & 380 & $\begin{array}{l}\text { Vorhies \& Morgan } \\
(2005)\end{array}$ & $\begin{array}{l}\text { Benchmarking marketing capabilities for sustainable } \\
\text { competitive advantage. }\end{array}$ \\
\hline 3 & 332 & $\begin{array}{l}\text { Habbershon, Williams, } \\
\& \text { MacMillan (2003) }\end{array}$ & A unified systems perspective of family firm performance. \\
\hline 4 & 320 & $\begin{array}{l}\text { Ethiraj, Kale, Krishnan, } \\
\text { \& Singh (2005) }\end{array}$ & $\begin{array}{l}\text { Where do capabilities come from and how do they matter? } \\
\text { A study in the software services industry. }\end{array}$ \\
\hline 5 & 247 & Zahra \& Nielsen (2002) & $\begin{array}{l}\text { Sources of capabilities, integration and technology } \\
\text { commercialization. }\end{array}$ \\
\hline 6 & 239 & $\begin{array}{l}\text { Hagedoorn \& Duysters } \\
(2002)\end{array}$ & $\begin{array}{l}\text { External sources of innovative capabilities: The preference } \\
\text { for strategic alliances or mergers and acquisitions. }\end{array}$ \\
\hline 7 & 223 & $\begin{array}{l}\text { Florin, Lubatkin, \& } \\
\text { Schulze (2003) }\end{array}$ & A social capital model of high-growth ventures. \\
\hline 8 & 178 & Hoffmann (2007) & Strategies for managing a portfolio of alliances. \\
\hline 9 & 167 & Verona \& Ravasi (2003) & $\begin{array}{l}\text { Unbundling dynamic capabilities: an exploratory study of } \\
\text { continuous product innovation }\end{array}$ \\
\hline 10 & 163 & $\begin{array}{l}\text { Gold, Seuring, \& Beske } \\
\text { (2010) }\end{array}$ & $\begin{array}{l}\text { Sustainable Supply Chain Management and } \\
\text { Inter-Organizational Resources: A Literature Review }\end{array}$ \\
\hline
\end{tabular}

Table 10. Scopus: Most cited papers about the relationship between $R \& C$

\begin{tabular}{|c|c|c|c|}
\hline Rank & TC & Authors & Title \\
\hline 1 & 1234 & Helfat \& Peteraf(2003) & The dynamic resource-based view: Capability lifecycles \\
\hline 2 & 464 & $\begin{array}{l}\text { Habbershon, Williams, } \\
\& \text { MacMillan(2003) }\end{array}$ & A unified systems perspective of family firm performance \\
\hline 3 & 205 & Verona \& Ravasi(2003) & $\begin{array}{l}\text { Unbundling dynamic capabilities: An exploratory study of } \\
\text { continuous product innovation }\end{array}$ \\
\hline 4 & 152 & $\operatorname{Deng}(2007)$ & $\begin{array}{l}\text { Investing for strategic resources and its rationale: The case } \\
\text { of outward FDI from Chinese companies }\end{array}$ \\
\hline 5 & 147 & $\begin{array}{l}\text { Jones, Lanctot, \& } \\
\text { Teegen (2001) }\end{array}$ & $\begin{array}{l}\text { Determinants and performance impacts of external } \\
\text { technology acquisition }\end{array}$ \\
\hline 6 & 119 & $\begin{array}{l}\text { Foerstl, Reuter, } \\
\text { Hartmann, \& Blome } \\
\text { (2010) }\end{array}$ & $\begin{array}{l}\text { Managing supplier sustainability risks in a dynamically } \\
\text { changing environment-Sustainable supplier management in } \\
\text { the chemical industry }\end{array}$ \\
\hline 7 & 113 & $\begin{array}{l}\text { Capron \& Mitchell } \\
\text { (2009) }\end{array}$ & $\begin{array}{l}\text { Selection capability: How capability gaps and internal } \\
\text { social frictions affect internal and external strategic renewal }\end{array}$ \\
\hline 8 & 106 & Yam et al. (2011) & $\begin{array}{l}\text { Analysis of sources of innovation, technological innovation } \\
\text { capabilities, and performance: An empirical study of Hong }\end{array}$ \\
\hline
\end{tabular}




\begin{tabular}{llll}
\hline 9 & 86 & $\begin{array}{l}\text { Chadwick \& Dabu } \\
(2009)\end{array}$ & $\begin{array}{l}\text { Kong manufacturing industries } \\
\text { Human resources, human resource management, and the } \\
\text { competitive advantage of firms: Toward a more } \\
\text { comprehensive model of causal linkages } \\
\text { Modelling integrated supply chain logistics in real-time } \\
\text { large-scale disaster relief operations }\end{array}$ \\
\hline
\end{tabular}

\section{Conclusion}

This bibliometric research was performed to compare two academic databases: WOS and Scopus, in terms of coverage and impact reached by each one. The comparison was performed using the same search equation in both databases and the specific subject chosen was: the relationship between resources and capabilities". The analysis of these two databases allows the identification of differences between the search methods, the operators to formulate the equation, the number of articles contained in each database, the importance of authors, the productivity of the journals and countries and the variability in the areas of knowledge for each database.

Regarding coverage, both databases offer powerful search engines and guarantee the inclusion of a comprehensive range of knowledge, nevertheless, the WOS proves to have a higher coverage.

With regards to productivity, both databases started with a similar number of papers published per year, and follow certain growing tendency, being 2010 the most productive year (27 papers in the WOS Vs. 13 in Scopus). Although they both started registering the same number of papers in 2001, WOS has been increasing the number of published papers in this area of knowledge, and, for 2016 the gap between both databases was considerable in terms of number of papers published (WOS=16, Scopus=6), being the WOS the most productive one.

The analysis by country reveals that the United States has the highest number of papers and the greatest number of citations. Europe and Asia by their side, are the two predominant continents in publishing in this field of knowledge. Even though the list of the top 20 countries regarding productivity do not exactly match for both databases, there is a common factor: the gap between USA and the other countries in terms of total productivity and total citations is really considerable. This fact has proven to be a pattern not only for this particular area of knowledge, but for the global productivity by countries.

As regards of authors, each one of the top 20 authors has published between 1 and 3 papers per year, regardless of the database used. In terms of the H-index, authors in the top 20 list by productivity have an $\mathrm{H}$-index lower than 4, which is an indicative either of the authors novelty character, or, the novelty of this particular subject of study, or either the low interest that academics have placed on the subject until today. In any case, this leaves a well-defined space for new research in this field.

There are big differences concerning to productivity and impact per journal. The WOS exhibit journals with a higher impact factor and productivity compared to Scopus (for the studied subject). There is a group of at least 7 journals (see Table 7) that concentrate the $50 \%$ of the top 20 publications by journal. Also "The Academy of Management Journal", has the highest impact factor among all the other journals, subsequently, it would be recommendable for a researcher interested on this topic, to take a close look at it.

Derived from all the analysis performed, the conclusion points at a shortage of studies of resources as foundations of firm's capabilities, therefore, the suggestion is to open new lines of research that allow enlightening the relationships among different resources and a variety of firm's capabilities. This becomes relevant as there is an already proven relationship between resources-capabilities and productivity of firms, therefore affecting the economy of regions and nations.

Lastly, it is important to highlight the advantages of bibliometrics, as it makes possible to evaluate the complete set of indexed publications in selected databases, for a certain period of time (Abramo \& D'Angelo, 2011). 


\section{References}

Abramo, G., \& D’Angelo, C. A. (2011). Evaluating research: from informed peer review to bibliometrics. Scientometrics, 87(3), 499-514.

Afshar, A., \& Haghani, A. (2012). Modeling integrated supply chain logistics in real-time large-scale disaster relief operations. Socio-Economic Planning Sciences, 46(4), 327-338. https://doi.org/10.1016/J.SEPS.2011.12.003

Albort-Morant, G., Leal-Rodríguez, A. L., Fernández-Rodríguez, V., \& Ariza-Montes, A. (2017). Assessing the origins, evolution and prospects of the literature on dynamic capabilities: A bibliometric analysis. European Research on Management and Business Economics. https://doi.org/10.1016/j.iedeen.2017.06.004

Albort-Morant, G., \& Ribeiro-Soriano, D. (2016). A bibliometric analysis of international impact of business incubators. Journal of Business Research. Elsevier Inc. https://doi.org/10.1016/j.jbusres.2015.10.054

Barney, J. B. (1991). Firm Resources and Sustained Competitive Advantage. Journal of Management, 17(1), 99-120. https://doi.org/10.1177/014920639101700108

Barney, J. B. (2001). Resource-based theories of competitive advantage: A ten-year retrospective on the resource-based view. Journal of Management, 27, 643-650.

Barney, J. B. (2007). Gaining and sustaining competitive advantage (3rd ed.). Upper Saddle River, New Jersey: Pearson Education.

Bauer, K., \& Bakkalbasi, N. (2005). An examination of citation counts in a new scholarly communication environment. D-Lib Magazine, 11(9).

Bordons, M., \& Zulueta, Á. M. (1999). Evaluación de la actividad científica a través de indicadores bibliométricos. Revista Española de Cardiología, 52(10), 790-800. Retrieved from http://www.revespcardiol.org/es/evaluacion-actividad-cientifica-travesindicadores/articulo/190/

Cadavid-Higuita, L., Awad, G., \& Franco-Cardona, C. J. (2012). A bibliometric analysis of a modeled field for disseminating innovation. Estudios Gerenciales, (28), 213-236.

Capron, L., \& Mitchell, W. (2009). Selection capability: How capability gaps and Internal social frictions affect internal and external strategic renewal. Organization Science, 20(2), 294-312. https://doi.org/10.1287/orsc.1070.0328

Chadwick, C., \& Dabu, A. (2009). Human resources, human resource management, and the competitive advantage of firms: Toward a more comprehensive model of causal linkages. Organization Science, 20(1), $253-272$.

Colakoglu, S., Yamao, S., \& Lepak, D. P. (2014). Knowledge creation capability in MNC subsidiaries: Examining the roles of global and local knowledge inflows and subsidiary knowledge stocks. International Business Review, 23(1), 91-101.

Cruz, J., López, P., \& Martín, G. (2009). La Influencia de las Capacidades Dinámicas sobre los Resultados Financieros de la Empresa. Cuadernos de Estudios Empresariales, 19(19), 105-128.

Daim, T. U., Rueda, G., Martin, H., \& Gerdsri, P. (2006). Forecasting emerging technologies: Use of bibliometrics and patent analysis. Technological Forecasting and Social Change, 73(8), 981-1012.

De Bakker, F. G., Groenewegen, P., \& Den Hond, F. (2005). A bibliometric analysis of 30 years of research and theory on corporate social responsibility and corporate social performance. Business \& Society, 44(3), $283-317$.

Deng, P. (2007). Investing for strategic resources and its rationale: The case of outward FDI from Chinese companies. Business Horizons, 50(1), 71-81. https://doi.org/10.1016/J.BUSHOR.2006.07.001

Dierickx, I., \& Cool, K. (1989). Asset stock accumulation and sustainability of competitive advantage. Management Science, 35(12), 1504-1511.

Escandón, D. M., Rodriguez, A., \& Hernández, M. (2013). La importancia de las capacidades dinámicas en las empresas born global colombianas. Cuadernos de Administracion, 26(47), 141-163.

Ethiraj, S. K., Kale, P., Krishnan, M. S., \& Singh, J. V. (2005). Where do capabilities come from and how do they matter? A study in the software services industry. Strategic Management Journal, 26(1), 25-45. https://doi.org/10.1002/smj.433

Falagas, M. E., Pitsouni, E. I., Malietzis, G. A., \& Pappas, G. (2008). Comparison of PubMed, Scopus, web of science, and Google scholar: strengths and weaknesses. The FASEB Journal, 22(2), 338-342.

Filippo, D. F. M. T., \& Fernández, M. T. (2002). Bibliometría: Importancia de los indicadores bibliométricos. El estado de la ciencia: principales indicadores deficiencia y tecnología Iberoamericanos/interamericanos. Buenos Aires 
(AR): Artes Gráfica Integradas.

Florin, J., Lubatkin, M., \& Schulze, W. (2003). A social capital model of high-growth ventures. Academy of Management Journal, 46(3), 374-384. https://doi.org/10.2307/30040630

Foerstl, K., Reuter, C., Hartmann, E., \& Blome, C. (2010). Managing supplier sustainability risks in a dynamically changing environment-Sustainable supplier management in the chemical industry. Journal of Purchasing and Supply Management, 16(2), 118-130. https://doi.org/10.1016/j.pursup.2010.03.011

Gold, S., Seuring, S., \& Beske, P. (2010). Sustainable supply chain management and inter-organizational resources: a literature review. Corporate Social Responsibility and Environmental Management, 17(4), 230-245.

Granda-Orive, J. I., Alonso-Arroyo, A., García-Río, F., Solano-Reina, S., Jiménez-Ruiz, C. A., \& Aleixandre-Benavent, R. (2013). Ciertas ventajas de Scopus sobre Web of Science en un análisis bibliométrico sobre tabaquismo. Revista Española de Documentación Científica, 36(2), 011. https://doi.org/http://dx.doi.org/10.3989/redc.2013.2.941.

Habbershon, T. G., Williams, M., \& MacMillan, I. C. (2003). A unified systems perspective of family firm performance. Journal of Business Venturing, 18(4), 451-465.

Hagedoorn, J., \& Duysters, G. (2002). External sources of innovative capabilities: The preference for strategic alliances or mergers and acquisitions. Journal of Management Studies, 39(2), 167-188. https://doi.org/Article

Haustein, S., \& Larivière, V. (2015). The use of bibliometrics for assessing research: Possibilities, limitations and adverse effects. In Incentives and Performance (pp. 121-139). Springer International Publishing. https://doi.org/10.1007/978-3-319-09785-5_8

Helfat, C. E., \& Peteraf, M. A. (2003). The dynamic resource-based view: Capability lifecycles. Strategic Management Journal, 24(10), 997-1010.

Hervas-Oliver, J. L., Sempere-Ripoll, F., \& Boronat-Moll, C. (2014). Process innovation strategy in SMEs, organizational innovation and performance: a misleading debate? Small Business Economics, 43(4), 873-886.

Hoffmann, W. H. (2007). Strategies for managing a portfolio of alliances. Strategic Management Journal, 28(8), 827856.

Jacsó, P. (2005). As we may search-comparison of major features of the Web of Science, Scopus, and Google Scholar citation-based and citation-enhanced databases. Current Science, 89(9), 1537-1547.

Jones, G. K., Lanctot, A., \& Teegen, H. J. (2001). Determinants and performance impacts of external technology acquisition. Journal of Business Venturing, 16(3), 255-283.

King, A. W. (2007). Disentangling interfirm and intrafirm causal ambiguity: A conceptual model of causal ambiguity and sustainable competitive advantage. Academy of Management Review, 32(1), 156-178.

Kleinbaum, A. M., \& Stuart, T. E. (2014). Network responsiveness: The social structural microfoundations of dynamic capabilities. The Academy of Management Perspectives, 28(4), 353-367.

Kulkarni, A. V., Aziz, B., Shams, I., \& Busse, J. W. (2009). Comparisons of Citations in Web of Science, Scopus, and Google Scholar for Articles Published in General Medical Journals. Jama, 302(10).

Lache, L., León, A. P., Bravo, E., Becerra, L. E., \& Forero, D. (2016). Las tecnologías de información y comunicación como prácticas de referencia en la gestión de conocimiento : una revisión sistemática de la literatura. Revista UIS Ingenierías, 15(1), 27-40.

Ma, H. (1999a). Anatomy of competitive advantage: A SELECT framework. Management Decision, 37(9), 709-718.

Ma, H. (1999b). Creation and preemption for competitive advantage. Management Decision, 37(3), $259-267$.

McKelvie, A., \& Davidsson, P. (2009). From resource base to dynamic capabilities: an investigation of new firms. British Journal of Management, 20(1).

Meho, L. I., \& Rogers, Y. (2008). Citation counting, citation ranking, and h-index of human-computer interaction researchers: A comparison of scopus and web of science. Journal of the American Society for Information Science and Technology, 59(11), 1711-1726. https://doi.org/10.1002/asi.20874

Morgan, N. A., Kaleka, A., \& Katsikeas, C. S. (2004). Antecedents of export venture performance: A theoretical model and empirical assessment. Journal of Marketing, 68, 90-108.

Morris, S., Hammond, R., \& Snell, S. (2014). A microfoundations approach to transnational capabilities: The role of knowledge search in an ever-changing world. Journal of International Business Studies, 45(4), $405-427$. 
Noruzi, A. (2005). Google Scholar: The New Generation of Citation Indexes. Libri, 54(4), 170-180.

Osareh, F. (1996). Bibliometrics, citation analysis and co-citation analysis: A review of literature I. Libri, 46(3), 149158. https://doi.org/10.1515/libr.1996.46.3.149

Petit, Y. (2012). Project portfolios in dynamic environments: Organizaing for uncertainty. International Journal of Project Management, 30(5), 539-553. https://doi.org/10.1002/pmj

Phusavat, K., \& Kanchana, R. (2007). Competitive priorities of manufacturing firms in Thailand. Industrial Management \& Data Systems, 107(7), 979-996.

Priem, R. L., \& Butler, J. E. (2001a). Is the resource-based "view" a useful perspective for strategic management research? Academy of Management Review, 26, 22-40.

Priem, R. L., \& Butler, J. E. (2001b). Tautology in the resource-based view and the implications of externally determined resource value: Further comment. Academy of Management Review, 26, 57-66.

Ray, G., Barney, J. B., \& Muhanna, W. A. (2004). Capabilities, business processes, and competitive advantage: Choosing the dependent variable in empirical tests of the resource-based view. Strategic Management Journal, 25(1), 23-37. https://doi.org/10.1002/smj.366

Rivera, H. A., \& Figueroa, L. S. (2013). Capacidades Dinámicas, una fuente de ventaja competitiva. Criterio Libre, $11(19), 245-261$.

Rueda-Klaussen Gómez, C. F., Villa-Roel Gutíerrez, C., \& Rueda-Klaussen Pinzón, C. E. (2005). Indicadores bibliométricos: origen, aplicación, contradicción y nuevas propuestas. Med UNAB, 8(1), 29-36. Retrieved from http://revistas.unab.edu.co/index.php?journal=medunab\&page=article\&op=view\&path\%5B $\% 5 \mathrm{D}=208 \% 5 \mathrm{Cnhttp}: /$ /revistas.unab.edu.co/index.php?journal=medunab\&page=article \&op=viewArticle \&path[]=208

Santhapparaj, A. S., Sreenivasan, J., \& Loong, J. C. K. (2006). Competitive factors of semiconductor industry in Malaysia: The managers' perspectives. Competitiveness Review, 16(3\&4), 197-211.

Schriber, S., \& Löwstedt, J. (2015). Tangible resources and the development of organizational capabilities. Scandinavian Journal of Management, 31, 54-68. https://doi.org/10.1016/j.scaman.2014.05.003

Sirmon, D. G., Hitt, M. A., \& Ireland, R. D. (2007). Managing firm resources in dynamic environments to create value: Looking inside the black box. Academy of Management Review, 32(1), 273-292.

Solano López, E., Castellanos Quintero, S., López Rodríguez del Rey, M., \& Hernández Fernández, J. (2009). La bibliometría: una herramienta eficaz para evaluar la actividad científica postgraduada. MediSur, 7(4), 59-62.

Teece, D. J., Pisano, G., \& Shuen, A. (1997). Dynamic Capabilities and Strategic Management. StraStrategic Management Journal, 18(7), 509-533.

Torres-Barreto, M. L. (2017). Product innovations and R \& D public funding: How to handle heteroscedasticity and autocorrelation. I+D Revista de Investigaciones, 9(1), 138-145.

Torres-Barreto, M. L., \& Antolinez, D. (2017). Exploring the boosting potential of intellectual resources and capabilities on firm's competitiveness. Espacios, 38(31), 35. Retrieved from http://www.revistaespacios.com/a17v38n31/a17v38n31p35.pdf

Torres-Barreto, M. L., Martínez, J. N., Meza-Ariza, L. C., \& Molina, L. P. M. (2016). El cambio tecnológico en el caso de los textiles inteligentes: Una aproximación desde las capacidades dinámicas. Espacios, 37(8).

Torres-Barreto, M. L., Mendez-Duron, R., \& Hernandez-Perlines, F. (2016). Technological impact of R\&D grants on utility models. $R \& D$ Management, 46(S2), 537-551.

Van Raan, A. F. (2003). The use of bibliometric analysis in research performance assessment and monitoring of interdisciplinary scientific developments. Technology Assessment-Theory and Practice, 1(12), 20-29. Retrieved from http://www.cwts.nl/TvR/documents/AvR-TFA2003.pdf

Vanhaverbeke, W., Duysters, G., \& Noorderhaven, N. (2002). External Technology Sourcing Through Alliances or Acquisitions: An Analysis of the Application-Specific Integrated Circuits Industry. Organization Science, 13(6), 714-733. https://doi.org/10.1287/orsc.13.6.714.496

Verona, G., \& Ravasi, D. (2003). Unbundling dynamic capabilities: an exploratory study of continuous product innovation. Industrial and Corporate Change, 12(3), 577-606. https://doi.org/10.1093/icc/12.3.577

Vorhies, D. W., \& Morgan, N. A. (2005). Benchmarking marketing capabilities for sustainable competitive advantage. Journal of Marketing, 69(1), 80-94. https://doi.org/10.1509/jmkg.69.1.80.55505 
Weeks, M. R. (2009). Sourcing practices and innovation: Evidence from the auto industry on the sourcing relationship as a dynamic capability. Innovation, 11(3), 304-326.

Wernerfelt, B. (1984). A resource-based view of the firm. StraStrategic Management Journal, 5(2), 171-180.

Wiklund, J., \& Shepherd, D. (2003). Knowledge-based resources, entrepreneurial orientation, and the performance of small and medium-sized businesses. Strategic Management Journal, 24(1), 307-1314.

Zahra, S. A., \& Nielsen, A. P. (2002). Sources of capabilities, integration and technology commercialization. Strategic Management Journal, 23(5), 377-398. https://doi.org/10.1002/smj.229

\section{Copyrights}

Copyright for this article is retained by the author(s), with first publication rights granted to the journal.

This is an open-access article distributed under the terms and conditions of the Creative Commons Attribution license (http://creativecommons.org/licenses/by/4.0/). 